\title{
DEPRESSION IN OPHTHALMOLOGICAL PATIENTS
}

\author{
Nada Pop-Jordanova ${ }^{1}$, Jovanka Ristova ${ }^{2}$, Sofija Loleska ${ }^{3}$ \\ ${ }^{1}$ Macedonian Academy of Sciences and Arts, Skopje, R. Macedonia \\ ${ }^{2}$ Okulus Ophtalmological Outpatient Clinic, Shtip, R. Macedonia \\ ${ }^{3}$ American College University, Skopje, R. Macedonia
}

Corresponding Author: Pop-Jordanova Nada, Macedonian Academy of Sciences and Arts, Bul. Krste Misirkov No 2 , Skopje, R. Macedonia, Tel: + 389 (0)2 32354 00, Fax + 389 (0)2 32355 00, E-mail: popjordanova.nadica@gmail.com

\begin{abstract}
Introduction: Vision is the most important sensorial part of the human information system. Visual loss leads to reduced ability to perform routine activities of daily living and can be a risk for stable mental health.

Aim: The aim of this cross-sectional study is to assess the incidence of depression in patients treated in an ophthalmological outpatient clinic. To our knowledge this is the first study of its kind in our country.

Subjects and method: The number of evaluated patients was a hundred; mean age $41.6 \pm 15.9$ years, with different educational levels and common ophthalmological disorders. For the assessment of the level of depression the Beck Depression Inventory was used. Patients were divided into two groups: serious ophthalmological diagnoses where we expected psychological problems $(\mathrm{N}=65)$ and the simplest ones $(\mathrm{N}=35)$ as a control.

Results: Obtained results show that the levels of depression correlate with the diagnoses. Patients in the first group (serious ophthalmological diagnoses) showed moderate depression in $12 \%$ and severe in $13 \%$ of patients. It was shown that the most depressed were the patients suffering from age-related macular degeneration and proliferative diabetic retinopathy, as well as glaucoma and cataract. The second group showed BDI scores of normal values. The level of depression is positively correlated with age and the level of education $(\mathrm{p}<0.05)$.

Conclusion: Depression is an important mental problem in ophthalmological practice. It is usually unrecognized and untreated. Depression could be the risk factor for treatment and prognosis of eyes diseases. Some measures for mitigation of psychological problems are proposed.
\end{abstract}

Key words: depression, ophthalmology, outpatients, mitigation.

\section{Introduction}

Eyes, being the organs of vision, detect light and convert it into electro-chemical impulses in neurons. Having these characteristics, vision is the most important sensorial part of the information system. Visual loss leads to reduced ability to perform routine activities of daily living. It is obvious that any kind of visual problem can be a risk for stable mental health. Patients with binocular disease have severe difficulties performing fine visual tests such as reading, and are often faced with serious lifestyle issues such as impending loss of a driver's license, work, and independence.

It has been described in many studies that depressive symptoms and anxiety are two common, practically normal responses to a glaucoma diagnosis. It is similar with other ophthalmological diseases, but in everyday practice mental health remains not so important. In addition, the medical school does not usually discuss the soft skill of how to talk to patients. On 
the patient's end, the Internet will often give inaccurate disease information or take facts out of context. Still, depressed, anxious, or cognitively impaired patients are less likely to adhere to their medication regimen, putting themselves at even greater risk of complications. On the other hand, new research shows that even minimal depression can affect visual function in agerelated macular degeneration (AMD) patients.

The aim of this cross-sectional study is to assess the incidence of depression in a sample of ophthalmological outpatients. To our knowledge this is the first study of this kind in our country.

\section{Method and subjects}

We randomly selected 100 patients, mean age $41.6 \pm 15.9$ years, with different eye problems and different educational levels. To assess depression, the Beck Depression Inventory (BDI) was applied.

The Beck Depression Inventory (BDI) is a multiple-choice, self-report inventory for measuring the severity of depression. We used the BDI revised in 1999 which contains 21 questions $[1,2]$.

The standard cut-offs are as follow: a score between 0-9 indicates minimal depresssion; 10-18 indicates mild depression; 19-29 indicates moderate depression; and 30-63 indicates severe depression. In other words, a higher score indicates more severe depressive symptoms.

Statistical analysis is done using the Statistica-8 package. For descriptive purposes, mean values and standard deviation of continuous variables and percentage for categorical variables are presented. Correlations were calculated with the Student's t-test. Statistical significance was taken at $\leq 5 \%$ level.

\section{Results}

As was mentioned previously, the number of evaluated patients was a hundred $(\mathrm{N}=100)$ with a mean age of $41.6 \pm 15.9$ years. Eye problems which we supposed to be related to the psychological status are displayed in Table 1.

The remaining 35 patients were diagnosed with chronic conjunctivitis, emetropia, astigmatisms, and simple hypermetropia, and this group is comprised as a control.
Table 1

Patients with serious ophthalmological problems

\begin{tabular}{|l|c|}
\hline Diabetic Retinopathy & 5 \\
\hline Glaucoma & 10 \\
\hline Age-related Macular Degeneration (AMD) & 10 \\
\hline Cataract & 10 \\
\hline High Myopia (Myopia Alta) & 5 \\
\hline Presbyopia & 25 \\
\hline
\end{tabular}

Figure 1 shows the level of education of examinees. As can be seen, the majority of evaluated patients completed secondary school.

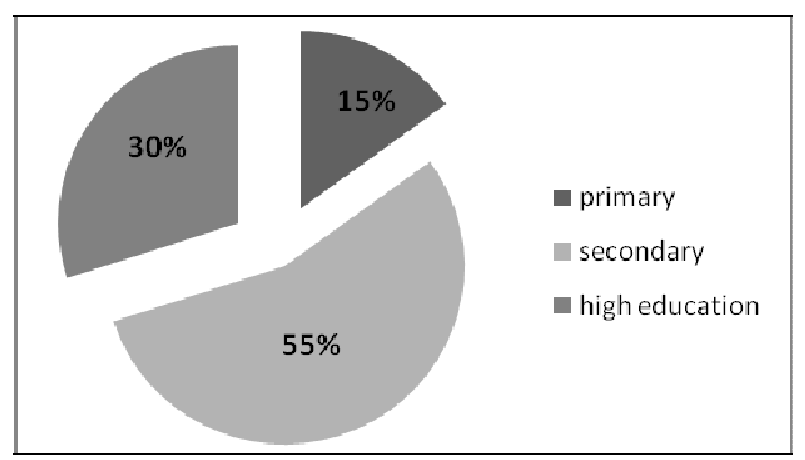

Figure 1 -Educational level of patients

Results obtained by BDI for all patients show that $50 \%$ of evaluated patients manifested minimal, $25 \%$ mild, $12 \%$ moderate, but as many as $13 \%$ severe depression (see Figure 2). This finding is very important because the moderate and severe depressions were unrecognized and untreated. It also raises the importance of deeper communication and support for all patients with vision problems.

The highest scores for depression indicating moderate and severe depression were obtained from patients with age-related macular degeneration, proliferative diabetic retinopathy, as well as with glaucoma and cataract. Obtained results for the 35 patients with minimal eye problems showed practically normal BDI scores (scores 0-9).

It is very important to point out that all patients with moderate or severe depression were over 50 years old.

Correlation between age and scores obtained with BDI are presented in Figure 3. As can be seen, we obtained a statistically significant positive correlation between these two variables $(r=0.56 \mathrm{p}<0.05)$, which seems very logical. 


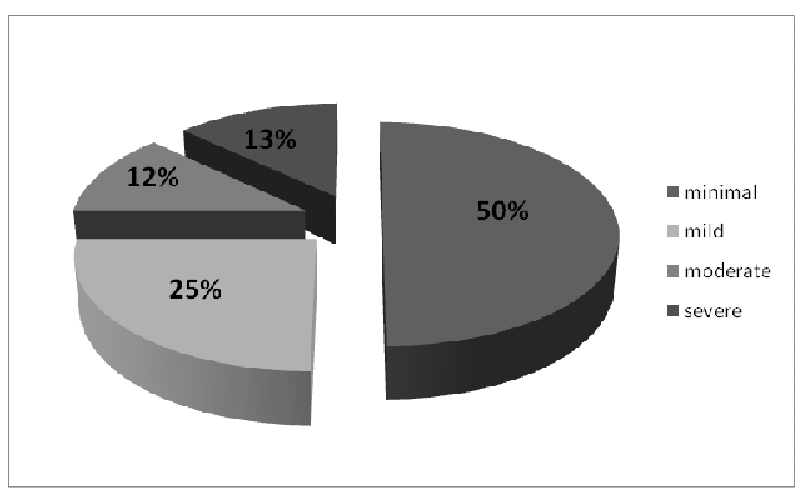

Figure 2 - The level of depression obtained by Beck Depression Inventory for all groups

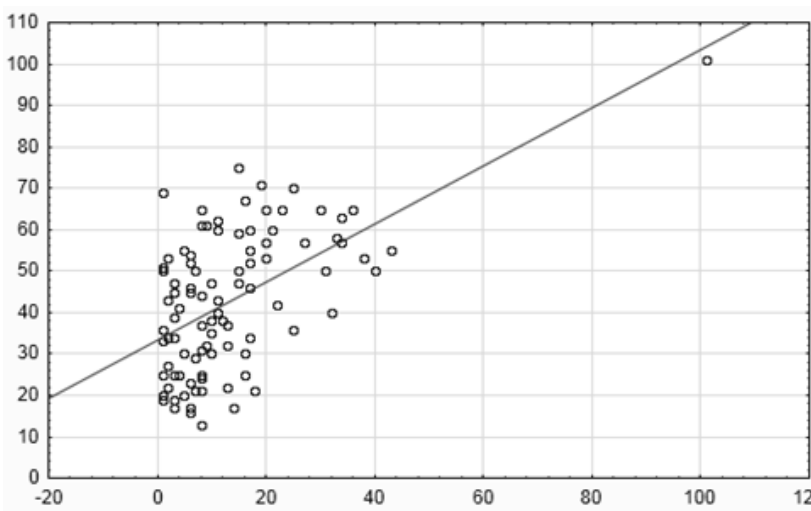

Figure 3-Correlation between obtained scores for depression and age

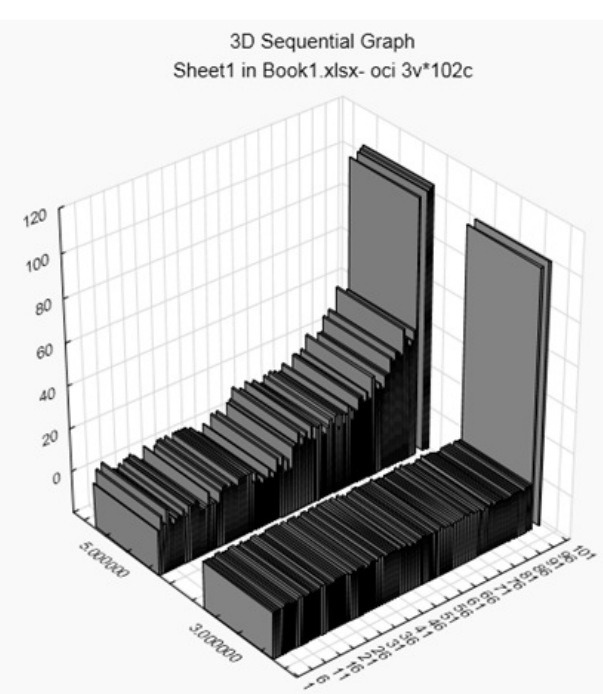

Figure 4 - Correlation between educational level and depression scores $(r=0.77 p<0.05)$

The scores obtained for depression are also significantly positively correlated with the level of education (Figure 4). This means that higher education leads to higher depression. More educated persons are more aware about the disease, but also their need for good vision is more important in everyday life.

\section{Discussion}

Our study shows that different levels of depression are present in patients with common ophthalmological diseases. However, moderate depression was recognized in $12 \%$ and severe in even $13 \%$ of all evaluated patients. The level of depression was related to the severity of eyes diagnoses. It was shown that the most depressed were patients with age-related macular degeneration (AMD), proliferative diabetic retinopathy, as well as those with glaucoma and cataract. These findings must be taken seriously.

In addition, it was shown that severe depression was detected mainly in the older population (over 50 years). These findings are similar to the results obtained in some other studies concerned with the psychological specifics in ophthalmological patients.

In a study by Brody et al. [3] from a total of participants comprising 151 adults aged 60 and older (mean age, 80 years) with advanced macular degeneration, $32.5 \%$ met the criteria for depressive disorder. In this context, authors proposed that the development of certain treatment strategies that teach patients to cope with vision loss is very important.

Zang et al. [4] in their study performed on a large national sample, provided evidence to generalize the relationship between depression and vision loss in adults across the age spectrum. The estimated prevalence of depression in this research was $11.3 \%$. They concluded that self-reported visual function loss, rather than loss of visual acuity, is significantly associated with depression. Health professionals should be aware of the risk of depression among persons reporting visual function loss.

Starting from the fact that psychological problems are age-related, Lee et al. [5] suggested that screening for geriatric syndromes in the eye clinic, being relatively rapid and easy to perform, could detect a significant number of patients with functional disability, depression, and possible dementia. This kind of screening is not usually performed in routine practice but could be very useful.

Studies that have examined rates of depression and anxiety in glaucoma patients have shown mixed results. The recent study from Yochim [6] tracked depression, anxiety, and cognitive impairment in older patients with 
glaucoma. Using a sample of 41 glaucoma patients, they found memory impairment in $20 \%$ of the sample and impaired executive functioning in $22 \%$. They also found mild to moderate depression symptoms in $12.2 \%$ of the participants. It was established that only one patient had significant anxiety.

Age-related macular degeneration (AMD) is a chronic, progressive eye disorder that mainly affects people over the age of 50. It is supposed that AMD affects approximately $10 \%$ of people aged $65-74$ years and $30 \%$ of those aged 75 and older, and is the major cause of blindness in old age. AMD is progressive and irreversible. Clinically, there are two types of AMD. Atrophic or "dry" AMD, also known as geographic atrophy, which is characterized by fatty deposits behind the retina (drusen) which cause thinning and drying of the macula. Dry AMD accounts for about $80 \%$ of cases affectting both eyes, but it typically causes only mild loss of vision. Neovascular AMD, or "wet" AMD, is caused by the growth of new blood vessels (choroid neovascularization). In the US, the estimated prevalence of AMD (neovascular and/or geographic atrophy) is $1.47 \%$, affecting approximately 1.75 million individuals. With progressive deterioration of the macula, AMD patients experience a multitude of visual problems that significantly affect their mental health and quality of life.

Many researches show that even minimal depression can affect visual function in age-related macular degeneration (AMD) patients. In a study by Livraj et al. [7] concerned with agerelated macular degeneration, 101 patients were evaluated. It was shown that $21.3 \%$ of patients endorsed severe symptoms of depression that had not yet been diagnosed.

Problem-solving intervention helps AMD patients to find solutions to daily challenges related to their visual problems. omprehensive treatment programmes that provide patients with optical aids and help them with psychosocial adjustment issues are also a great help to patients and could improve their quality of life [8-13].

Dry eyes are a common problem in aged people. In a study by Labee et al. [14] the association between dry eye symptoms and depression in an adult population was evaluated. Findings confirmed that the depression score was correlated with dry eye symptoms (the obtained correlation coefficient was $r=0.07 ; p=0.013$ ).

In a study comprising patients with acute anterior uveitis - AAU [15] it was found that during an acute attack, AAU patients suffered from depressive moods more often than their healthy peers (obtained scores for Beck Depression Inventory BDI was 54\% vs. 9\%, respectively). In our study we had no patients with this diagnosis.

Prevalence of anxiety and depression among glaucoma patients is relatively high. Self-reported measures were informative in evaluating patients' psychological disturbances. One cross-sectional study included 506 Chinese glaucoma patients. The prevalence of anxiety and depression in Chinese glaucoma patients was $22.92 \%$ and $16.40 \%$, respectively. Findings in other studies are very similar [16$18]$.

High myopia is another problem among ophthalmological patients. Yokoi T. et al [19] found that the incidence of depression in patients with high myopia was $22.0 \%$ and the incidence of anxiety disorder was $25.9 \%$, which raises these issues as very important. In addition, high myopia is a risk of retinal detachment. The latest eye problem also influences the mental health. A high level of anxiety and depression was found in patients with retinal detachment [20], which seems very logical to us. In our study, obtained results confirmed that patients with high myopia manifested mild depression.

Generally, all more severe eye problems have a high impact on patients' daily life and cause restrictions of their psychological well-being, autonomy and mobility. For this reason, the role of doctors and nurses involved in the treatment of ophthalmological disorders is very subtle.

There are ways that ophthalmologists can help patients to decrease depressive symptoms or anxiety, suggests Caceres V. [21, 22]. It all begins with setting the right tone when speaking with patients. Doctors must choose words carefully, and deliver a positive message when possible. Although, for example, glaucoma or AMD can be blinding diseases, with the right compliance, the prognosis could be better and there are many promising treatments for the future. 
In addition, doctors and nurses must contain the control of their own anxiety about the disease of the patients. For all diseases, especially for glaucoma, it is important to tell patients that controlling the disease is a team effort - and that they are part of that teamwork. By emphasizing this, we give the patients a sense of control over the disease. Education helps the patients to have a sense of control, which will lessen depression and anxiety.

It is important to acknowledge especially when things are going well. Positive reinforcement helps to counteract the negative news that is often part of the glaucoma patients' visits. Finally, when necessary, all patients with psychological problems must be referred to mental health professionals.

\section{Conclusion}

Our study shows that different levels of depression are present in patients in the ophthalmological setting. Moderate depression was found in $12 \%$ and severe in as many as $13 \%$ of evaluated patients. However, depression was an unrecognized and untreated problem.

The level of depression is related to the severity of diagnosis. Patients with diabetic retinopathy, age-related macular degeneration, glaucoma and cataract were more depressed. Patients with high myopia manifested mild depression.

A positive correlation between depression and age and educational level was confirmed.

Bearing in mind that stabile mental health is important for the treatment and prognosis of eye problems, it is suggested that psychological support be given, and specific methods for mitigation (such as biofeedback, relaxation training) for obtaining better adjustment and collaboration of patients.

\section{REFERENCES}

1. Steer RA, Ball R, Ranieri WF, Beck AT. Dimensions of the Beck Depression Inventory-II in clinically depressed out pa tients. J Clin Psychol. 1999; 55(1): 117-128.

2. Steer RA, Cavalieri TA, Leonard DM, Beck AT. Use of the Beck Depression Inventory for Primary care to screen for major depression disorders. Gen Hosp Psych. 1999; 21(2): 106-111.

3. Brody BL, Gamst AC, Williams RA, Smith AR, Lau PW, Dolnak D, Rapaport MH, Kaplan RM, Brown SI. Depression, visual acuity, comorbidity, and disa- bility associated with age-related macular degeneration. Ophthalmology. 2001; 108 (10): 1893-900.

4. Zhang X, Bullard KM, Cotch MF, Wilson MR, Rovner BW, McGwin G, Owsley C, Barker L, Crews JE, Saaddine JB. Association Between Depression and Functional Vision Loss in Persons 20 Years of Age or Older in the United States, NHANES 20052008 , JAMA Ophthalmol. 2013; 131(5): 573-581.

5. Lee AG, Beaver HA, Jogerst G, Daly JM. Screening elderly patients in an outpatient ophthalmology clinic for dementia, depression, and functional impairment. Ophthalmology. 2003; 110(4): 651-7.

6. Yochim BP, Mueller AE, Kane KD, Kahook MY. Prevalence of cognitive impairment, depression, and anxiety symptoms among older adults with glaucoma. J Glaucoma. 2012 Apr-May; 21(4): 250-4.

7. Jivraj J, Jivraj I, Tennant M, Rudnisky C. Prevalence and impact of depressive symptoms in patients with age-related macular degeneration. Can J Ophthalmol. 2013 Aug; 48(4): 269-73. doi: $10.1016 /$ j.jcjo.2013.03.007

8. Yuzawa M, Fujita K, Tanaka E, Wang EC. Assessing quality of life in the treatment of patients with agerelated macular degeneration: clinical research findings and recommendations for clinical practice. Clin Ophthalmol. 2013; 7: 1325-32. doi:

10.2147/OPTH.S45248. Epub 2013 Jul 1

9. Jivraj J, Jivraj I, Tennant M, Rudnisky C. Prevalence and impact of depressive symptoms in patients with age-related macular degeneration. Can J Ophthalmol. 2013 Aug; 48(4): 269-73. doi:

10.1016/j.jcjo.2013.03.007

10. Yuzawa M, Fujita K, Tanaka E, Wang EC. Assessing quality of life in the treatment of patients with agerelated macular degeneration: clinical research findings and recommendations for clinical practice. Clin Ophthalmol. 2013; 7: 1325-32. doi: 10.2147/OPTH.S45248. Epub 2013 Jul 1

11. Mitchell J, Bradley C. Quality of life in age-related macular degeneration: a review of the literature. Klin Monbl Augenheilkd. 2010 Aug; 227(8): 646-52.

12. Meyer-Ruesenberg B, Richard G. [New insights into the underestimated impairment of quality of life in age-related macular degeneration - a review of the literature]. Klin Monbl Augenheilkd. 2010 Aug; 227(8): 646-52.

13. Mitsuko Yuzawa, Kyoko Fujita, Erika Tanaka, and Edward C Y Wang Assessing quality of life in the treatment of patients with age-related macular degeneration: clinical research findings and recommendations for clinical practice. Clin Ophthalmol. 2013; 7: 1325-1332.

14. Labbé A, Wang YX, Jie Y, Baudouin C, Jonas JB, $\mathrm{Xu}$ L. Dry eye disease, dry eye symptoms and depression: the Beijing Eye Study. Br J Ophthalmol. 2013 Nov; 97(11): 1399-403.

doi: 10.1136/bjophthalmol-2013-303838. Epub 2013 Sep 7.

15. Maca SM, Wagner J, Weingessel B, Vécsei-Marlovits PV, Gruber K, Schiesser AW. Acute anterior uveitis is associated with depression and reduction of 
general health. Br J Ophthalmol. 2013 Mar; 97(3): 333-7. doi: 10.1136/bjophthalmol-2012-302304. Epub 2013 Jan 19

16. Zhou C, Qian S, Wu P, Qiu C. Quality of life of glaucoma patients in China: sociodemographic, clinical, and psychological correlates-a cross-sectional study. Qual Life Res. 2013 Sep 24. [Epub ahead of print]

17. Zhou C, Qian S, Wu P, Qiu C. Anxiety and depresssion in Chinese patients with glaucoma: sociodemographic, clinical, and self-reported correlates. J Psychosom Res. 2013 Jul; 75(1): 75-82. doi: 10.1016/j.jpsychores.2013.03.005. Epub 2013 Apr 11

18. Wang SY, Singh K, Lin SC. Prevalence and predictors of depression among participants with glaucoma in a nationally representative population sample. Am J Ophthalmol. 2012 Sep; 154(3): 436-444.e2. doi: 10.1016/j.ajo.2012.03.039. Epub 2012 Jul 11

19. Yokoi T, Moriyama M, Hayashi K, Shimada N, Tomita M, Yamamoto N, Nishikawa T, Ohno-Matsui $\mathrm{K}$. Predictive factors for comorbid psychiatric disorders and their impact on vision-related quality of life in patients with high myopia. Int Ophthalmol. 2013 Jun 21. [Epub ahead of print].

20. Mozaffarieh M, Sacu S, Benesch T, Wedrich A. Mental health measures of anxiety and depression in patients with retinal detachment. Clin Pract Epidemiol Ment Health. 2007 Jul 19; 3: 10.

21. Caceres V. Managing fear and depression in glaucoma patients, GLAUCOMA, 2013, BioMed Central Ltd. Open Access

22. Caceres V. Minimal depression can affect AMD patients' visual function, OPHTHALMOLOGY NEWS, 2007, BioMed Central Ltd. Open Access.

\section{Резиме}

\section{ДЕПРЕСИЈА КАЈ ОФТАЛМОЛОШКИТЕ ПАЦИЕНТИ}

\section{Нада Поп-Јорданова ${ }^{1}$, Јованка Ристова ${ }^{2}$, Софија Лолеска ${ }^{3}$}

${ }^{1}$ Македонска академија на науките и уметностите, Скопје, Р. Македонија

2 Офталмолошка амбуланта „Окулус“, Штип, Р. Македонија

${ }^{3}$ Универзитет Американски колеџ, Скопје, Р. Македонија
Вовед: Видот претставува најважниот сензорен дел на хуманиот информационен систем. Губењето на видот доведува до смалена способност за изведба на рутинските активности во секојдневното живеење и може да биде ризик за стабилното ментално здравје.

Цел: Цел на оваа пресечна студија е да се испита инциденцијата на депресија кај пациенти третирани во амбулантска офталмолошка служба. Според наше сознание, ова претставува прва студија од ваков вид во нашата земја.

Испитаници и метод: Бројот на испитаници беше сто, со средна возраст 41,6 \pm 15.9 години, со различен степен на едукација и со најчести офталмолошки растројства.

Пациентите беа поделени во две групи: оние со сериозни офталмолошки дијагнози кај кои очекувавме психолошки проблеми $(\mathrm{H}=65)$ и пациенти со едноставни дијагнози $(\mathrm{H}=35)$ кои претставуваат контролна група

За испитување на степенот на депресија е користен Беков инвентар за депресија.

Резултати: Добиените резултати покажаа дека степенот на депресија корелира со дијагнозата. Пациентите од првата група (сериозни офталмолошки дијагнози) покажаа средна депресија во 12\%, додека висока во $13 \%$. Втората група покажа БДИ-скорови во нормални граници.

Покажано е дека најмногу депресивни се пациентите со сенилна макуларна дегенерација, со пролиферативна дијабетична ретинопатија, како и оние со глауком и катаракта. Степенот на депресија е позитивно корелиран со возраста, како и со нивото на образование $(\mathrm{p}<0,05)$.

Заклучок: Депресијата е значаен ментален проблем кај офталмолошките пациенти. Таа најчесто е непрепознаена и нетретирана. Депресијата може да биде ризик за самиот третман, како и за прогнозата на очните болести. Предложени се некои мерки за ублажување на овој проблем.

Клучни зборови: депресија, офталмологија, амбулантски болни, ублажување. 